\title{
Aesthetics of Representing Cultural Paradigms in Rushdie
}

\author{
Meenu A. Gupta \\ Department of English and Cultural Studies, Panjab University, Chandigarh, India.
}

\author{
How to cite this paper: Meenu A. Gupta. \\ (2020) Aesthetics of Representing Cultural \\ Paradigms in Rushdie. Journal of Humani- \\ ties, Arts and Social Science, 4(2), 99-108. \\ DOI: $10.26855 /$ jhass.2020.07.003 \\ Received: August 3, 2020 \\ Accepted: August 27, 2020 \\ Published: September 8, 2020 \\ *Corresponding author: Meenu A. \\ Gupta, Department of English and Cul- \\ tural Studies, Panjab University, Chan- \\ digarh, India. \\ Email: mun110275@gmail.com
}

\begin{abstract}
In the contemporary century where the world is metamorphosed to a global village, the concept of national culture and national literature is certainly belied. The world literature, today, simultaneously represents an important multicultural perspective within individual national literatures as well as more global perspective taking in the phenomena of transculturalism and diaspora confluence. Raymond Williams develops a theory of relation between culture at large and cultural products like literature. Culture is manifested in human artifacts and activities such as music, literature, life-style, food, painting, sculpture, theatre and film. It can be said that arts and the world of science with their moral systems come to form culture. These are constantly in a spatio-temporal flux that renders an inexhaustible range of meanings and a catalogue of the elements. In this process of evolution a particular aspect dominates or fades off at some space-time coordinate. The pattern of human activity and the symbolic structures give such activities significance and importance. Rushdie, like other postcolonial writers not only reflects upon the political aspects of history but also deconstructs the interrelationships between history and individual to delve into the moral and psychological tensions of the native homeland. His novels are the fine example where ethics of the nation are well represented in the aesthetics of his works. The paper is a research work that delves into Rushdie's novels to look for various cultural representations.
\end{abstract}

\section{Keywords}

Culture, Rushdie, Aesthetics, Cultural Paradigms, Miscegenation, Hybridity

\section{Introduction}

In the contemporary century where the world is metamorphosed to a global village, the concept of national culture and national literature is certainly belied. The world literature, today, simultaneously represents an important multicultural perspective within individual national literatures as well as more global perspective taking in the phenomena of transculturalism and diaspora confluence. Centripetal and centrifugal forces can be discerned as both antagonistic and complementary forces in cultural development. Raymond Williams develops a theory of relation between culture at large and cultural products like literature. Culture is manifested in human artifacts and activities such as music, literature, life-style, food, painting, sculpture, theatre and film. It can be said that arts and the world of science with their moral systems come to form culture. These are constantly in a spatio-temporal flux that renders an inexhaustible range of meanings and a catalogue of the elements. In this process of evolution a particular aspect dominates or fades off at some space-time coordinate. The pattern of human activity and the symbolic structures give such activities significance and importance. 
Rushdie, like other postcolonial writers not only reflects upon the political aspects of history but also deconstructs the interrelationships between history and individual to delve into the moral and psychological tensions of the native homeland. His novels are the fine example where ethics of the nation are well represented in the aesthetics of his works. Rushdie himself has come to represent pop culture and has always been a powerful figure in re-presenting culture in his writings and this paper is an attempt to decipher a pattern in this representation. Rushdie's self-avowed purpose in writing the novels is to highlight "the connection between public affairs and private lives". "You cannot separate the two", says he (The Sunday Standard 6). They interpenetrate and that is how the writer needs to examine them, the one in the context of the other. Georg Lukacs says in this regard:

True great novelist depicts man and society as complete entities, instead of showing merely one or the other of their aspects. (p. 6)

In this context Walter Allen writes:

... contemporary novels are the mirrors of the age, but a very special kind of mirror that reflects not merely the external features of the age but also its inner face, its nervous system, coursing of its blood, and the unconscious promptings and conflicts which sway it. (pp. 18-19)

Though Walter Allen had said this taking in consideration the novels of his times it holds pretty agreeable to this era also.

Rushdie's works are a postmodernist experiment with miscegenation where fiction merges with not only criticism, political history, biography but also with the society. Salman Rushdie says that by killing the novel we attempt to kill society. Murder the story, and you annihilate the soul. "The novel" says Rushdie, is "the stage upon which the great debates of society can be conducted" (italics original) (Is Nothing Sacred? Imaginary Homelands, p. 420). He writes, not only to entertain or to amuse but to provoke and to question, as he puts it, "everything in every possible way" (Is Nothing Sacred? Imaginary Homelands, p. 429). This puts forth his moral purpose of exposition and correction. Rushdie says that no passport can describe his identity; and that his loyalties are to ideas and not to places. He writes, he says, as a "secular, pluralist man". We can say that he rejoices in eclecticism. Sandel writes in the same context, "Political community depends on the narratives by which people make sense of their condition, and interpret the common life they share”. (p. 350)

The Enchantress of Florence-Cultural Co-existence : If we consider the works of Rushdie there seem to be a pattern of representing culture in its varied aspects that culminates in his latest production The Enchantress of Florence. It is a fine example of cultural coexistence ages before the contemporary globalised world in the $16^{\text {th }}$ century. In the beginning of the novel, readers ride back to the $16^{\text {th }}$ century Fatehpur Sikri in a "rented bullock cart" with a traveler named Mogor.

With its caravanserai, turbaned coolies in red shirts and dhotis, the city of Fatehpur Sikri had a cushioned pleasure. Only noises of delights were permitted to be heard: "the bells on the ankles of dancers", "fountains tinkled", and the soft music of the genius Tansen:

....there was much languid play, with slave girls being used as living pieces on the chequerboard floor. In the curtained afternoons beneath the sliding punkahs there was a quiet time for love. (p. 28)

When Mogor told that he has with him the queen's letter, the Emperor comments that unlike Spain, England is the home of art and beauty. It is Elizabeth of England who is the true reflection of the emperor's greatness and style:

Warming to his theme, he explained that the faraway redhead queen was nothing less than the Western mirror of the emperor himself, she was Akbar in female form, and he, the Shahanshah, the king of kings, could be said to be an Eastern Elizabeth, mustachioed, non-virginal, but in the essence of their greatness they were the same. (p. 69)

This man from the West, excellent in Persian, is an example of generational migrancy centuries back. When the messenger talks of "great polytheist pantheons" of Florence, Akbar too talks of millions and more gods that are worshipped in Hindustan. And the narrative seems to be a dream to Akbar whose "cloak cut from the cloths of time and space and these people were not his". (p. 141) Still, he felt a strange sense of kinship which enabled him surprisingly to understand "their unspeakable European tongue as it were his own". Two cultures take on a blended polarity in the fascinating character of Akbar where each culture becomes the dream of the other.

When Mogor is narrating that how Filipepi painted the dead first enchantress of Florence, Simonetta Cattaneo as to raise her from the dead which reminds Akbar: 
“The same as Dashwanth", the emperor marveled.

This may be the curse of the human race,' responded Mogor. "Not that we are so different from one another, but that we are so alike". (italics original 137)

Not only the painters and Enchantresses but the whore pairs also have their counterparts. If Fatehpur had Skeletal Mohini-Mattress pair, Florence had Scandal-La Matterassina to offer to its customers. The connecting link between the two cities and epochs is the magically beautiful hidden princess, Qara Koz. In a radio talk to Vibhuti Patel, Rushdie himself refers to the similar courtesan bawdy culture of Moghul Rule and Italian Renaissance. In both the places the aristocratic families had locked up girls and arranged marriage was some kind of a pact or a treaty. As a result, menfolk ventured out for sequestered women of easier virtues. These brothels were a sort of cultural clubs with musicians, witty wits and glamorous figures of the society.

The cause of the death of Birbal in the novel is the uprising of the Raushanai cult, whose leader had stirred Hinduism and Islam together and come up with pantheistic stew of amorality. Birbal was disgusted.

Because God is in everyone and everything, it follows that all acts are divine acts, and therefore, because all acts are godly, there is no difference between right and wrong, good deed, and evil ones, and so we may do exactly as we please? (p. 314)

This, Birbal says is scoff at Jahanpanah's desire to find the one faith within all faiths. Towards the end of the novel and the story of Mogor dell'Amore, the emperor understands the cultural difference between the humdrum people of the East and exotic West in the East people worked hard and lead normal lives as against surreal people who were prone to hysterias of all sorts. And in this hysteric rush of gold they went further west and took it to be India. Akbar found this offensive:

Men and women who made human sacrifices to their gods were being called Indians! ...little better than aborigines; ....Their god was made of smoke. ...suffered from syphilis and thought of stones and the rain and stars as living beings....They did not believe in change. To call these people Indians was in Akbar's emphatic opinion a slight to te noble men and women of Hindustan. (p. 330)

Therefore, this novel is a success in yoking the historical periods of two extreme places. Though in actuality they were fifty years apart but readers accept the median drawn by Rushdie without any cognizable difference.

Midnight's Children-Beginnings: Even in his earlier novels, whatever the main plot might be, the cultural background has been significant to the aesthetics of the work. A major theme of Midnight's Children is the predicament of the modern Indian, grappling with the unique history of the country, split between the tendency to affiliate with Indian cultural traditions but attracted to Western values. Tai's ancestral oriental world, an epitomized view of an ageless, changeless, organic cosmos presents a contrast to the secular outlook. Midnight's Children is an intense and revealing exploration of India's culture and politics: humorous observations like “... the water shortage had reached the point where milkmen could no longer find clean water with which to adulterate the milk...”, and wildly imagined events where a communist snake charmer induces a pair of cobras to act out a rich man refusing to give alms to a beggar, police harassment, hunger, disease, and illiteracy. The swapping of kids allows Rushdie to portray the real India—a multiplicity of parallel dimensions-Hindu/Parsi/Islamic as well as mega-rich/shockingly poor simultaneously along with other pluralities. Other elements that define the prevalent culture are usage of superstition, celluloid world of films, peep-show men. The narrow lanes and crowded streets had drainpipe dormitories, beggars in box-cars, grown-up men with babies' legs and Indian beggars.

When he talks of Bombay his fondness for the city offers holistic view of local Kolis, their festivals of "Coconut Day", fondness for rice, style of draping sari and pomp of Ganesh Chaturthi. Rushdie makes use of all religions, although his choice of material is unbiased but true to the ethics of the work. Hinduism, with its millions of gods, its fluid mythology and absorptive, transformative energies, conceptualizes India's inclusiveness. The author, though Muslim himself, is representative of Indian culture; he expresses his fondness that "despite my Muslim background, I'm enough of a Bombayite to be well up in Hindu stories, and actually I'm very fond of the image of trunk-nosed, flap-eared Ganesh solemnly taking dictation”. (Rushdie,1982, p. 177)

Rushdie is known for taking symbols and figures from different myth systems and religions, interweaving and juxtaposing them: themes from Islam and Hinduism are interwoven with figures from English literature and English literary references. His work advocates that the cultural exchange brought about by the Empire has enriched rather than cheapened contemporary literature. On this aspect Rushdie comments:

I'm also very fond of myth, but it isn't possible to sit down and say that I will now write a myth. Myth is a 
cultural accumulation - a collective experience, not an individual achievement-and you can learn from and use its shapes, since they provide strength in the work. (Haffenden, 1985, p. 247)

The characters like Padma, Parvati and Shiva bearing mythical names provide a religious touch but are delineated in modern terms. The mythical image of Shiva is subjected to subversions in socio-cultural terms. All these minute details are there in the novel not without reason but more than being a part of the setting they are important in their own way as they help in forming the social ethos. In Midnight's Children, for instance, pickled chutney is one of the main images for India's cultural and social maelstrom; a dense, discursive epic of post-Independence India, it fuses baroque realism and a Shandean narratorial voice with a spirit of storytelling deeply informed by oral and folk traditions.

Shame, shame about counter-culture: Shame, Rushdie's next novel is a black comedy of public life. It focuses on the social mores of the backward and superstitious Islamic society that multiplies on the vice of shame, through limitless repression, creating violence, anarchy, social tension, political uncertainty and restlessness among the general public. Shame and shamelessness are "the architecture of the society that the novel describes" (Fernandez, 1984, p. 105). They are the "roots to violence” (Rushdie, 1983b, p. 116). Strange things can take place and we are descriptively given a picture of such an atmosphere:

Shameful things are done: lies, loose living, disrespect for one's elders, failure to love one's national flag, incorrect voting at elections, over-eating, extramarital sex, autobiographical novels, cheating at cards, maltreatment of womenfolk, examination failures, smuggling, throwing one's wicket away at the crucial point of a Test Match: and they are done shamelessly. (Rushdie, 1983b, p. 122)

Sufiya and Shakil are the typical products of such a cultural climate of Pakistan that serves as the background of the novel. Family stories, Rushdie says, "were the glue that held the clan together, binding the generations in webs of whispered secrets" (Rushdie, 1983b, p. 76). The family as centre is integral to the traditional culture of any nation. The influence of marriage on Indian women can be clearly seen by studying Rani and Bilquis. Both women are victimized by tradition and they gain a sense of material security as a part of the package of this cultural misogyny.

Rushdie has given positive treatment to his women characters and it is pertinent to hold that Rushdie is distinguishing between male-dominated traditions and female-dominated ones. Out of all female characters, only Arjumand Harappa is a prototype of the phase in Western Feminism where women professionals have to pay the price of spinsterhood and childlessness. Naveed's fertility at the level of political allegory is symbolic of Pakistan's population explosion but at the level of social satire it exaggerates women's lack of autonomy in decisions regarding progeny. Rushdie has sketched different tints of women. Pinkie is another strong, self-confident woman with scant regard for the sanctity of marriage vows and her dotard husband.

Rushdie also shows concern over the wronged social status of women. He suggests the cage-like life of Omar's mothers who led a cloistered existence because their father raises them in strict conformity with 'an irony morality that was mostly Muslim' (Rushdie, 1983b, p. 130). Sufiya is the perfect-victim figure; she suffers for all the females, as the society dominated by its men-folk has to meet its cultural obligations. The reference to the Islamic Calendar indicates the repressive life of the people dragged backward and chained to the Middle Ages; the world where heroes are clowns and clowns are heroes, where fair is foul and foul is fair. Iskander Harappa once told his daughter:

"As a nation we have a positive genius for self-destruction, we nibble away at ourselves, we eat our children, we pull down anyone who climbs up” (Rushdie, 1983b, p. 184).

The novelist expresses his desire:

... that Islam might well have proved an effective unifying force in post-Bangladesh Pakistan, ... Maybe

Sindhis, Baluchis, Punjabis and pathans, not to mention immigrants, would have sunk their differences for the sake of their common faith. (Rushdie, 1983b, p. 251)

Rushdie's linking of his fictitious exploits of Naveed “Good News" with the real case of Anahita Muhammad, the Punjabi girl in London shot dead by her own father for bringing shame on the family by making love to a white boy is the tangential attack on Rushdie's major theme of cultural transplant.

Palimpsest-ual Culture of The Moor's Last Sigh: Palimpsest is a dominant metaphor in Shame and also in The Moor's Last Sigh where culture is seen as an eclectic amalgamation from diverse social groups. Rushdie in this evolution deals with transition from unicultural to multicultural depiction. He attempts to deal with a mélange of composite cultures, which is India. Moorish Spain can be seen as a fusion of cultures-Spanish, Moorish, Jewish, the 
"Peoples of the Book" - which came apart at the fall of Granada. Like Midnight's Children, here also Rushdie's fondness for the Hindu-God Ganesha is conspicuous. Though Rushdie's idea of plurality represents that of the entire world, it is deeply rooted in his own understanding of the Indian ethos- past, present and future.

For a nation of seven hundred millions to make any kind of sense, it must base itself firmly on the concept of multiplicity, of plurality and tolerance, of devolution and decentralization wherever possible. There can only be one way—religious, cultural, or linguistic — of being an Indian; let difference reign. (Rushdie, 1991, p. 44)

The ethos of the land — the homeland that he has carried and cultivated in his imagination while in exile—enables him to regard India with a degree of hope for an enlightened future. As he expresses his intention that the character in The Moor's Last Sigh who says motherness is our biggest idea certainly speaks what I consider to be the truth. Another important device used by Rushdie where magical signifies the composite nature of contemporary Indian culture and society is celluloid. The idea of "motherness" is explored in the Indian context by taking the instance from Bollywood. Moor is born in the year Mehboob Productions' movie Mother India is made. Rushdie in The Moor's Last Sigh offers, through his characters, the humorous definitions of modern Indian democracy ("one man, one bribe") and the Theory of Relativity ("everything is for relatives") which shows that there is no final morality in affairs of state. Vasco's 'Indian Variation' upon the theme of Einstein's General Theory D=mc2 is a bizarre pun on Indian polity and power:

Everything is for relative. Not only light bends, but everything. For relative we can bend a point, bend the truth, bend employment criteria, bend the law. D equals mc squared, where $\mathrm{D}$ is for Dynasty, $\mathrm{m}$ is for mass of relatives, and c of course is for corruption, which is the only constant in the universe- because in India even speed of light is dependent on load shedding and vagaries of power supply. (Rushdie, 1995, p. 272)

Here we can relish the admixture of polity, society and science to cater each other beautifully and the resultant humour lends the acrid but subtle pun on the Indian favouritism. This is reflected in Midnight's Children also where Saleem recalls a ditty sung by Mary Periera long ago.

Anything you want to be, you kin be.

You kin be just what-all you want. (Rushdie, 1982, p. 457)

Rushdie also toys with the nature of mother-son relationships in Indian and Pakistani societies, emphasizing the perversion of their closeness.

Hoopoe weaves the Native Narrative: The hoopoe in Haroun and Sea of Stories comes to represent both the ancient tradition of Sanskrit storytelling from which Attar has taken him and the value of the narrative arts in which he is adept. Through this novel, Rushdie establishes a univocal interpretation of culture, and the story sea is a living embodiment of heteroglossia and polyphony. When Haroun asks why he hates stories so much, given that stories are such fun, Khattam Shud replies:

"The world, however, is not for Fun. ...The world is for Controlling”.

"Which world?” Haroun made himself ask.

"Your world, my world, all worlds”, came the reply. “They are all to be Ruled. And inside every single story,

inside every Stream in the Ocean, there lies a world, a story-world, that I cannot Rule at all...” (p. 161)

This "free" society is represented in Haroun by the Guppees who defend the story sea because it reflects the diversity of their own community, a multicultural utopia. A free society in which there are no limits to what can be said and what can be told, Rushdie is suggesting, will always prove stronger than a society that is superficially bound by imposed government policy and enforced ideology. In theory, freedom of expression leads toward a more tolerant society in which a multitude of different, competing ideas can coexist side by side. In practice, however, it is usually the case that, even in societies in which there is no direct censorship, indirect censorship based on various social and economic factors will still operate. These Orientalist elements, however, do not represent attempts to incorporate the non-European narrative into the substance and body of the story; neither do they represent attempts to convey the spirit of Arabic or Sanskrit storytelling to a new readership. On the contrary, they isolate fantastic or absurd features of the non-European narrative tradition to emphasize their strangeness, and to play upon European ideas of the foreign and exotic. Rushdie, by contrast (although this is a contentious point) aims to transform the genre by placing both narrative traditions on an equal footing, by showing how the two are interdependent and intertwined. This 
radical transformation in the way that the two cultures interact is prelude to a total reassessment of their understanding of one another. Each realizes that the other is not as bad, or as different, as they first thought-and both realize that the distinctive differences between the two cultures can provide opportunities for productive exchange rather than destructive enmity.

Rushdie's fantasy, by contrast, demonstrates a resistance to the tradition's exclusive reliance on European narrative forms and European modes of perception by taking this tradition, saturated in British folklore and fairy tale, and merging it with an equivalent tradition in Indian storytelling that derives from Indic, Persian, or Arabic oral and literary sources. In addition to a host of character types and scenarios reminiscent of Western fairy tales, for instance, Rushdie gives us plot motifs and expressions from The Arabian Nights, Bhatta Somadeva's eleventh-century Ocean of Streams of Story (Katha Sarit Sagara), and, as we have seen, Attar's The Conference of the Birds. There are Indian and Middle Eastern precedents for a tale that is now predominantly thought of as European. The implication of this is that the tales of different cultures are not separated from one another by rigid cultural divides and "walls of force" (7) but may share a number of significant features.

If "cultural difference" is understood as "the free play of polarities and pluralities in the homogenous empty time of the national community" (p. 162), Bhabha has argued, then multiculturalism becomes little more than an argument for a cultural relativism in which all are equal because all are the same, and all are included because no one is different. The number 1001 in Rushdie's fiction thus comes to represent what Bhabha has called "the insurmountable extremes of storytelling [where] we encounter the question of cultural difference as the perplexity of living and writing the nation” (p. 161).

Pop Culture Sways The Ground Beneath Her Feet: The Ground Beneath Her Feet is Rushdie's reworked myth of Orpheus and Eurydice set in a postmodern world which has the period of 50's till 90's rock music as a backdrop. The narration by the world famous photographer Rai is a celebration of pop-culture and the mythology of celebration. Starting with the last day of Vina's life, the shadows of love and death hang over the novel. From there to Bombay of the 1950s, Rai's narrative unravels nearly a half-century of pop culture. Ormus and Vina's relationship reflects a higher kind of love of an almost divine magnitude, re-enacting Orpheus and Eurydice, Kama and Rati. Combining the historical and mythological with mainstream 20th century pop culture, Rushdie has created a novel of earthy, dark beauty, rendering love on an immortal scale both believable and real. Besides these major characters, even the minor characters of the novels provide the most vivid portraits of the cultures and backgrounds that come into play in the story. Sir Darius Cama and his English friend Methwold over their meetings explore the relationships between Indian and European mythological traditions. Methwold gets to know that the Greek god Ouranos was none other than India's own Varuna, thus proving the common heritage of all Aryan culture:

The abduction of Helen of Troy by Paris and that of Sita of Ayodhya by the demon king Ravana; the relationship between Hanuman, the wily monkey god, and the devious Odysseus; the parallels between the tragedy of the House of Atreus and that of Rama's clan: ....tripartite theory.... all Aryan cultures rested on the triple concept of religious sovereignity, physical force and fertility—that this was the real Trinity that defined both Eastern and Western civilization, their common bond? (pp. 41-42)

And by plunging deeper from the surface of contemporary life they become happier as they seek refuge in the eternal. They had delightfully examined parallels between the scenes from the Illiad and Ramayana (p. 44). Its not only the comparative mythology but the nomenclature with subtle humour that foreshadows the nativity of its culture. Even, during last hours of his life he derives Greek heroes Prometheus and Epimetheus from Puranic Pramanthu and Manthu, and also the swastika, that ancient Indian fire symbol was stolen by Nazis and defiled. Piloo Doodhwala had daughters Halva and Rasgulla and they had insulted V. V. Merchant, and amusingly the insult for which:

The Hindustani word kutti is inadequate for my purposes, suggesting as it does a rather petulant, almost childish level of quarrel. This was not kutti. This was vendetta. (p. 69)

After euphemistic kutti, there is another paragraph inviting the nostalgia of the kiteflyers devoted to the kit-festival - “tecnicolor diamonds”, manja reels, including the kite fighters' special battle thread, black gut dipped in a suspension full of tiny shards of broken glass. Kala manja (p. 216). And this becomes a family name.

The Merchants are the converts and Piloo strongly believes that religious converts do not have any cultural leanings. He defines "religious converts" in a humorous vein:

"You know what is it? I will tell. Religious conwersion, it is like getting on a train. Afterwards, only the train itself is where you are belonging. Not departure platform, not arrival platform. In both these places you 
are totally despised. Such is conwert. It is your goodfather's phorefather”. (p. 70)

Further, when Merchant family is discussing Vina and her village in US, Ameer Merchant comments that Red Indian names are quite similar to South Indians like Oatacamund, Thekkady, Chittoor, Chickaboom as if "some of our Dravidian co-nationals sailed off to America yonks ago in a beautiful pea-green boat. Indians get everywhere, isn’t it? Like sand” (p. 82). Yes, they do. Rushdie interestingly defines culture himself:

What's a "culture”? Look it up. "A group of micro-organisms grown in a nutrient substance under controlled conditions". A squirm of germs on a glass slide is all, a laboratory experiment calling itself a society. Most of us wrigglers make do with life on that slide; we even agree to feel proud of that "culture". Like slaves voting for slavery or brains for lobotomy, we kneel down before the god of all moronic micro-organisms and pray to be homogenized or killed or engineered; we promise to obey. (p. 95)

And Vina and Ormus were two bespoken identities who insisted on what one might call "auto-couture" and with the music Ormus, the "culture traitor" has poured "the trash of America into our children's ears" and glorified the base/low culture. Even in their suspended love, the divine absence filled with the fantasies explains culture. "The culture needs a vacuum to rush into, it is an amorphousness in search of shapes". These fantasies take the centre place of our lives in the "pure Platonic essence" and makes sense of the rest.

Vina dies and Ormus starts visiting Goddess-Ma, who represents sect of India saints who can travel anywhere without visas and immigration records. They reverberate the so-called Wisdom of the East and find nuclear experiments to be betrayals of the land's true spirit. This Goddess-Ma fuses Indian mythology with Greek and believes that there has always been a woman keeping things together beneath the unstable earth in all cultures:

Our Indian earth mother parted her lips to receive pure Sita, falsely accused of having been defiled by Ravana, after Lord Ram rejected her on his spin doctors’ advice. Our Greek mother Persephone sits beside Hades in his subterranean kingdom.

Now Vina, our beloved Vina, has joined these women, the greatest of women, who hold up the earth from below as mighty Atlas holds up the sky. (p. 496)

And like Lord Shiva danced, Greek Eurynome loved dancing and "if the earth shakes" Vina dance too to unveil new miracles.

Cosmopolitan fury: In the Fury, Rushdie's protagonist Malik Solanka is a part-creator of a culture he hardly understands - a modern cultural malaise. The urban culture of New York and Webspeak fuses tradition with novelty in terms of language and themes both. Both Fury and The Ground Beneath Her Feet explore the relationship of the artist with his creation. Solanka, a Cambridge philosopher and doll maker is a possible serial-killer and unknowingly a creator of a pop-culture phenomenon that comes to represent everything he despises about modern cultural malaise. Rushdie in his narratives often indulge in the migration or contemporary adventure narratives, the migrants are often caught in the conundrum of socio-cultural displacement beckoned by the homeliness of their native lands.

The usage of popular American culture in Fury allows readers to relate directly to Rushdie's main character Malik Solanka, and suspend their disbelief to permit more implausible events to take place. Rushdie immerses Solankas's personal life events into the mainstream culture of at-that-time America and this brings the character to life. The influence of popular culture in Solanka's dramatic scenes implies the universality of America, and helps to apply the idea that America is everywhere. By purposely inserting popular American cultural references into his novel, Salman Rushdie asserts both credibility and possibility into Malik Solanka's story, as well as familiarization with Solanka's character. Rushdie's numerous allusions of American culture effect the attitude of the audience, and gradually allow the acceptance of implausible acts to complete the possibility of Solanka's life as true; because, when the audience can accept the universality of popular culture, acceptance of an individuals' life in that culture become just as feasible. It gives the globalised view of New York city which boiled with money:

Rents and property values had never been higher, and in the garment industry it was widely held that fashion had never been so fashionable. New restaurants opened every hour....the skyrocketing demand for ever more recherche produce:...(p. 3)

Metropolis is a place where the commonplace is as commonplace as diet soda, that abnormality was the popcorn norm. And a migrant from a different culture silently prayed "Eat me, America, and give me peace” (p. 44). Against this milieu the mother-tongue that was used in The Enchantress to unleash abuse by a polyglot is desired to be forgotton here as Solanka cries that he would "rip his lying mother tongue out" of his throat and speak broken English 
instead. And yes, America seduces him:

What he opposed in it he must also attack in himself. It made him want what it promised and eternally withheld. Everyone was an American now, or at least Americanized... Even anti-Americanism was Americanism in disguise... (p. 87)

But still India or better still Indianism is insisted upon and infused everywhere, like Neela's apartment was in "the overemphasised manner of the diaspora: the filmi music, the candles and incense, the Krishna-and-milkmaidscalendar, the dhurries on the floor, the Company School painting, the hookah coiled atop a bookcase...” (p. 208)

Motherland subculture at work: Large societies often have subcultures that differentiate them from a larger culture. Shalimar The Clown operates at multi-levels predominately politics, history, great plot and unparalled use of language but all at the backdrop of culture. There is a bucolic valley where Muslims live in peace with their Hindu neighbors. The two religions co-exist peacefully in this town and borrow from one another; the Muslims adapt the Hindu's gods and superstitions while the Hindus learn to include meat in their daily cooking. Embodying this syncretic culture is Pachigam, a village of theatrical performers and cooks, where the love between Muslim tightrope walker Shalimar and Hindu actress named Boonyi triumphs over religion.

Rushdie has many a times expressed his affection and concern for Kashmir and this novel is a clear crystal reflection of Kashmiriyat or Kashmiriness: in names like Boonyi-kashmiri chinar tree, Pamposh-lotus flower, Giriwalnut kernel, Nazarebaddoor — “evil, eye, begone!” and honorifics like sher; local langue—wazwaan-banquet of Thirty-Six Courses Minimum, bhand pather-comic stories, dastarkhans-the floor-clothes surrounded by bolster cushions, shamiana for tents, vasta waza - a grand chef and pandit - a scholarly doctor. Even the wild beasts of Kashmir have the native names according to their character and habits. (p. 91) Kashmiriness is the belief that at the heart of Kashmiri culture there is a common bond that transcends all other differences. Most villages were Muslim but Pachigam was a mixture where not only "Kashmiriness" was to be protected but Pachigaminess as well. And the marriage of two inter-religion lovers was acceptable and observed with Hindu and Muslim customs both. The marriage ceremony is treat arranged for the readers where they enjoy the melody of the "non-sectarian instruments" like Santoor, Sarangi, rabab and harmonium. Kauls bride dress consisted of tarang (headgear), phiran and haligandun belt and Norman family insisted on wearing a red lehanga and shalwar-kameez for their yenvool (Muslim wedding procession) and bridegroom would wear sherwani and a karakuli topi. The American ambassador, Mr Maximilian Ophuls evidently took a strong interest in all aspects of kashmiri culture. On his visit to Kashmir the Kasmiri music and food was arranged for him, bhands would perform stories from "gigantic Kashmiri story-compendium $\mathrm{Ka}$ tha-sarit-sagar, which made the Arabian Nights look like a novella” (p. 132). A dance number Anarkali was also arranged from the all-time successful Hindi movie Mughal-e-Azam.

The American ambassador to India who is also the scion of a cultured Ashkenazi family, a hero of the French Resistance and a chum of Marlon Brando's falls for Boonyi and the two elope to Delhi. Towards the end of the narration in the section Shalimar the Clown, the readers again have the pleasure to observe the interweaving of the ongoing plot with the eternal story of the Ramayana but of course with the modern inversion:

In the old story Sita the pure was kidnapped and Ram fought a war to win her back. In the modern world everything had been turned upside down and inside out. ... Boonyi ...had freely chosen to run off with her American Ravan and willingly became his mistress and bore him a child; and Ram-the Muslim clown, Shalimar, misplaying the part of Ram-fought no war to rescue her.In the old story, Ravan had died rather than surrender Sita. In the contemporary bowdlerization of the tale, the American had turned away from Sita and allowed his queen to steal her daughter and send her home in shame. In ancient tale, when Sita returned to Ayodhya after defending her chastity throughout her captive years, Ram had sent her back into forest exile because her long residence under Ravan's roof made that chastity suspect in the eyes of the common people. In Boonyi’s story, ...exiled to forest, but it was the people-...saved her life... (p. 263)

Shalimar goes mad with jealousy, and vows to kill the two lovers. As he gets deranged, so does Kashmir. The novel induces the feeling of the absolute loss of a paradise, the destruction of the Utopian Culture. This is a classic example that surfaces the tolerance of Indian culture which might remain apparently hidden under the dirty game of politics. Like some of the post-9/11 literature it delves deep into the root of terrorism and explores the turmoil generated by different faiths and cultures attempting to co-exist. We witness the peaceful ethnic religious acceptance transforming into a violent conflict. 


\section{Conclusion}

Culture, myths, religion, tradition, heritage—blend and merge, presenting a curiously hybrid picture. One of the areas that this study on cultural representation also focuses on is inclusion of literary allusions and the creative use of language, highlighting their global perspective as mentioned in the novels of Rushdie. The critical framework used is based on the theories of magic realism, intertexuality, historiographic metafiction, indeterminacy, deconstruction, hybridity, fragmentation, parody and so on. These harmonize the universal and the particular and, in the process, it seems to open up to a multiplicity of cultural relationships unheard of in the age of empire: for Pieterse, it is through hybridity that globalization works against "homogenization, standardization, cultural imperialism, westernization, Americanization". We can aptly conclude that that part of the attraction of postcolonial theory to questions of globalization lies precisely in its claim that culture, as a social and conceptual category, has escaped "the bounded nation-state society" and has thus become the common property of the world. (Mike)

The following Table 1 (mine tabulation) shows at a glance the presence of various cultures in the novels, the techniques that the author uses and through various paradigms which enables him to showcase them.

Table 1. Paradigms and Techniques of the various cultures in the novels of Rushdie

\begin{tabular}{|c|c|c|c|}
\hline Novel & Culture & Techniques & Paradigms \\
\hline Midnight's Children & colonial exchange & \multirow{8}{*}{$\begin{array}{l}\text { Magic Realism } \\
\text { Fragmentation } \\
\text { Hybridity } \\
\text { Miscegenation } \\
\text { Palimpsest } \\
\text { Native Language } \\
\text { Intertextuality } \\
\text { Parody } \\
\text { Indeterminacy }\end{array}$} & \multirow{8}{*}{$\begin{array}{c}\text { society cross-section } \\
\text { History } \\
\text { native vocabulary } \\
\text { language } \\
\text { traditions } \\
\text { Ceremonies } \\
\text { Characterisation } \\
\text { Nomenclature } \\
\text { family units } \\
\text { religion } \\
\text { Art, dance } \\
\text { politics }\end{array}$} \\
\hline Shame & anti-culture & & \\
\hline The Moor's Last Sigh & Multiculture & & \\
\hline Ground Beneath the Feet & pop culture & & \\
\hline Fury & global culture & & \\
\hline Haroun and Sea of Stories & cross-culture & & \\
\hline Shalimar The Clown & regional culture & & \\
\hline The Enchantress of Florence & a spatio-temporal & & \\
\hline
\end{tabular}

Clinton Bennett in his thesis Concord and Discord in Multicultural Societies: The Clash of Cultural Values expresses his concern of which Rushdie also mentions: that the narratives they tell can deliberately exclude some others from having a right to share either the story or the common life. This applies to myths that peoples and nations tell about themselves, myths which privilege some ethnicities over others, or which effectively demonize others as the enemy, on to whom responsibility for all our woes and ills can so easily be displaced.

Thus, this paper was an attempt to take up the interdependence and co-existence of public and private affairs primarily in their historical perspective. It takes an individual and his history out to reach society along with its culture, traditions, myth and religion. Rushdian world is fused with flavours from tradition and modernity, religion, culture, plurality, and blended well. Thus, we can conclude that the works of Rushdie shows a kind of comic inversion that is to understand a creation, one need to comprehend the world around him.

Overlooking this limitation restricted to only post-colonial works, we find that there are many ways in which Rushdie reveals social facts in his novels. Somewhere he gives specific information about social institution or customs that exist, about the laws that prevail and proscriptions of religion. Whereas, at the other places, the readers can infer the information about values, norms, expectations in the society from the attitudes of the characters in fiction and their behaviour. The diversities always prevailed, the difference is in response. Earlier the attempt was to absolutely eradicate differences and now the postmodern "hoopoe" celebrates this diversity.

\section{References}

Allen, Walter. (1971). Reading a Novel. Great Britain: Penguin, pp. 18-19.

Cundy Catherine. (1994). "Through Childhood's Window—Haroun and the Sea of Stories”. M. D. Fletcher (ed.), Reading Rushdie- Perspectives on the Fiction of Salman Rushdie, Cross Cultures, 16, Amsterdam/Atlanta, Rodopi.

Dilip Fernandez. (1984). "Such Angst, Such Loneliness, Such Rootlessness”. Gentleman, Feb. 1984, p. 101.

Durix, J-P. (1994). “'The Gardener of Stories’-Salman Rushdie’s Haroun and the Sea of Stories”. M. D. Fletcher (ed.), Reading Rushdie -Perspectives on the Fiction of Salman Rushdie, Cross Cultures, 16, Amsterdam/Atlanta, Rodopi. 
Featherstone, Mike. (n.d.). “Global Culture: An Introduction”. Global Culture, 2.

Haffenden, John. (1985). “Salman Rushdie.” Novelists in Interview, New York: Routledge, Chapman and Hall, p. 237.

Kirschenbaum, M. (2015). “What is an @uthor?” Los Angeles Review of Books, February 6. lareviewofbooks.org/essay/uthor/.

Lukacs, Georg. (1962). The Historical Novel. trans. Hannah and Stanley Mitchell. London: Merlin Press.

Lukacs, Georg. (1968). “The Ideology of Modernism” in David Lodge, ed. $20^{\text {th }}$ Century Literary Criticism: A Reader, London, pp. 465-87.

Ravy, T. (2016). “'The Man Who Would Be Popular’: An Analysis of Rushdie’s Twitter Feed”. Journal of Commonwealth Literature, 52 (3): 551-562. doi:10.1177/0021989416678284.

Ravy, Tawnya. (2018). "Reframing Salman Rushdie: The Politics of Representation and New Media in Transnational Public Culture.” PhD diss., The George Washington University.

Risam, R. (2017). “Colonial and Postcolonial Digital Humanities Roubdtable”. https://acrl.ala. org/dh/2017/11/02/resource-colonial-and-postcolonial-digital-humanities-roundtable/.

Rushdie, Salman, ed. (1997). The Vintage Book of Indian Writing 1947-97. London: Vintage.

Rushdie, Salman. (1982). Midnight's Children. New York: Avon.

Rushdie, Salman. (1983a). “The Indian Writer in England.” In The Eye of the Beholder, edited by Maggie Butcher. London: Commonwealth Institute.

Rushdie, Salman. (1983b). Shame. New Delhi: Picador.

Rushdie, Salman. (1988). The Satanic Verses. London: Viking.

Rushdie, Salman. (1990a). Haroun and the Sea of Stories. New York: Penguin.

Rushdie, Salman. (1990b). Haroun and the Sea of Stories. London: Penguin Granta.

Rushdie, Salman. (1990c). “In Good Faith.” Sunday, 25 Feb.-3 March, p. 27.

Rushdie, Salman. (1991). Imaginary Homelands: Essays and Criticism: 1981-1991. New Delhi: Penguin Viking India.

Rushdie, Salman. (1995). The Moor's Last Sigh. London: Vintage.

Rushdie, Salman. (1996). “In Defense of the Novel, Yet Again: Fiction has Never Been Safe.” The New Yorker. 24 June and 1 July 1996: 48-55.

Rushdie, Salman. (2000). The Ground Beneath Her Feet. London: Vintage.

Rushdie, Salman. (2001). Fury. London: Jonathan Cape.

Rushdie, Salman. (2005). Shalimar The Clown. London: Jonathan Cape.

Rushdie, Salman. (2008). The Enchantress of Florence. London: Jonathan Cape.

Sandel, Michael J. (1996). Democracy's Discontent: America in Search of a Public Philosophy. Cambridge, MA: Harvard University Press.

Teverson, Andrew S. (2001). Twentieth Century Literature, Vol. 47, No.4, Salman Rushdie. (Winter, 2001$)$, pp. $444-466$.

Williams, Raymond. (n.d.). Marxism and Literature. Oxford: OUP, pp. 192-3. 